\title{
Pengaruh Moralitas Pajak, Budaya Pajak, Dan Good Governance Terhadap Kepatuhan Wajib Pajak
}

\author{
Indar Khaerunnisa ${ }^{1}$, Adi Wiratno ${ }^{2}$ \\ ${ }^{1}$ Universitas Pancasila, Jl. Srengseng Sawah, Jagakarsa, Jakarta Selatan 12640 \\ ${ }^{2}$ Universitas Jenderal Soedirman, Jl. Prof. Dr. HR. Boenyamin No. 107, Purwokerto 53122 Jawa Tengah
}

\section{N F O A R T I K E L}

\author{
JEL Classification: \\ H26
}

Keywords:

morality tax, tax culture, good governance, taxpayer compliance

\section{A BSTRACT}

This study aims to determine, first, the effect of tax morality as measured by the level of citizen participation, confidence level, the level oflocal autonomy, national pride, demographic factors, economic conditions, the deterrence factors, and taxation systems towards compliance paja. Second, the effect of the tax culture that consists of respondents to react to the tax culture the form of relationships between tax authorities and the taxpayer, tax regulations and national culture on tax compliance. Third, the effect of good governance such as human resources, information technology, organizational structure, processes and procedures, financial resources and incentives for corporate tax compliance. The sample is a company that is a member of Gabungan Pelaksana Konstruksi Nasional Indonesia (Gapensi Data obtained by sending a questionnaire to members Gapensi Bogor. A total of 80 respondents were analyzed by using Partial Least Square (PLS). Hypothesis testing results show that there are significant tax morality, culture tax and good governance toward tax compliance

\section{A B S T R A K}

Penelitian ini bertujuan untuk mengetahui, pertama, pengaruh moralitas pajak yang diukur dengan tingkat partisipasi warga negara, tingkat kepercayaan, tingkat otonomi daerah, kebanggaan nasional, faktor demografis, kondisi ekonomi, deterrence factors, dan sistem perpajakan terhadap kepatuhan paja. Kedua, pengaruh budaya pajak yang terdiri dari responden memberikan reaksi terhadap budaya pajak yang berupa hubungan antara aparat pajak dan Wajib Pajak, peraturan perpajakan dan budaya nasional terhadap kepatuhan pajak. Ketiga, pengaruh good governance berupa sumber daya manusia, teknologi informasi, struktur organisasi, proses dan prosedur, sumber daya finansial dan insentif terhadap kepatuhan pajak perusahaan. Sampel adalah perusahaan yang menjadi anggota Gabungan Pelaksana Konstruksi Nasional Indonesia (Gapensi). Data diperoleh dengan cara pengiriman kuesioner kepada para anggota Gapensi kota Bogor. Sebanyak 80 responden dianalisis dengan menggunakan

*Email Korespondensi: '1shenizada@yahoo.com, 2adiwiratno08@yahoo.com 
Least Partial Square (PLS). Hasil pengujian hipotesis menunjukkan bahwa terdapat pengaruh moralitas pajak, budaya pajak, dan good governance terhadap kepatuhan wajib pajak

\section{Pendahuluan}

Riset mengenai kepatuhan pajak sebelumnya yang dilakukan oleh Widodo (2010) menggunakan variabel moralitas pajak, dan budaya pajak sebagai variabel independen dan kepatuhan pajak sebagai variabel dependen. Penelitian dilakukan dengan metode survey terhadap 480 responden wajib pajak yang tersebar di enam kota besar di Indonesia, yaitu Jakarta, Makasar, Medan, Surabaya, Yogyakarta dan Bandung. Adapun responden adalah mereka yang berusia 17 tahun ke atas yang dipilih melalui metodologi acak sistematis.

Terinspirasi dari penelitian tersebut maka penulis tertarik untuk membuat replikasi penelitian tersebut, bentuk replikasi yang dibuat oleh penulis yaitu dari segi variabel dependen dan Independen. Variabel independen yang dipergunakan adalah moralitas pajak dan budaya pajak, untuk variabel dependen menggunakan kepatuhan wajib pajak, namun kemudian penulis menambahkan variabel independen lain yaitu good governance, hal itu dilakukan karena berdasarkan penelitian bahwa good governance merupakan variabel dapat mempengaruhi kepatuhan pajak (Theresia, 2009). Responden pada penelitian Widodo adalah responden yang berusia 17 tahun ke atas yang dipilih melalui metodologi acak sistematis, sedangkan untuk penelitian ini penulis menggunakan adalah wajib pajak badan anggota GAPENSI Kota Bogor. Penulis sangat tertarik untuk melakukan penelitian ini kembali karena sebelumnya penulis pernah tergabung sebagai anggota GAPENSI Bogor, berdasarkan pengamatan selama menjadi anggota tersebut banyak hal yang ditemui mengenai kepatuhan pajak anggota yang sangat unik. Responden menjadi lebih menarik untuk diteliti karena GAPENSI sebagai asosiasi pengusaha konstruksi dan pengadaan di Bogor, dimana hampir semua wajib pajak badan yang ikut serta dalam kegiatan pengadaan dan konstruksi di Bogor wajib menjadi anggota dalam asosiasi ini. Hal yang menjadikannya semakin menarik karena disebabkan pendapatan pajak yang diterima Kota Bogor 64\% berasal dari wajib pajak badan, dimana $83 \%$ dari pendapatan wajib pajak badan tersebut berasal dari sektor konstruksi dan pengadaan (Iskandar, 2012). Mengenai budaya pajak, dalam ekonomi umumnya hanya terdapat sedikit bukti empiris dan eksperimen yang membahas mengenai pengaruh budaya. Dalam area kepatuhan pajak, studi lintas budaya adalah hal yang baru dan riset terbaru mengikat faktor pelaporan pajak yang relevan bersifat konstan, dan karenanya dapat secara lebih baik mengikat faktor perbedaan budaya yang mungkin terjadi. Berdasarkan uraian di atas, beberapa pokok permasalahan yang akan dibahas lebih lanjut dalam karya akhir adalah sebagai berikut :

1. Bagaimana pengaruh moralitas pajak yang berupa tingkat partisipasi warga negara, tingkat kepercayaan, tingkat otonomi daerah, kebanggan nasional, faktor demografis, kondisi ekonomi, deterrence factors, dan sistem perpajakan terhadap kepatuhan pajak.

2. Bagaimana pengaruh budaya pajak yang terdiri dari responden memberikan reaksi terhadap budaya pajak yang berupa hubungan antara aparat pajak dan Wajib Pajak, peraturan perpajakan dan budaya nasional terhadap kepatuhan pajak.

3. Bagaimana pengaruh good governance berupa sumber daya manusia, teknologi informasi, struktur organisasi, proses dan prosedur serta sumber daya finansial dan insentif terhadap kepatuhan pajak.

Pajak adalah sumber pendanaan yang berkesinambungan untuk pembangunan, Pajak juga merupakan penghubung antara negara dengan warga negaranya, sedangkan penerimaan pajak merupakan urat nadi bagi kontrak sosial pemerintah dengan masyarakatnya, dimana kontrak sosial merupakan pilihan sosial atau pilihan kolektif atas ketentuan pemenuhan barang dan jasa publik bagi masyarakat sebagai imbal balik dari pembayaran pajak yang dilakukan (Ayee, 2008). Unsur-unsur pokok dari definisi di atas, yaitu : iuran atau pungutan, dipungut berdasarkan Undang-undang, pajak dapat dipaksakan, tidak menerima atau memperoleh kontraprestasi, dan untuk 
membiayai pengeluaran umum Pemerintah (Nurmantu, 2003).

Moralitas pajak dapat didefinisikan sebagi motivasi instrinsik untuk membayar pajak yang timbul dari kewajiban moral atau keyakinan untuk berkontribusi kepada negara dengan membayar pajak (Torgler, 2003). Moralitas pajak tidak mengukur perilaku individu, namun lebih kepada sikap dan pendirian individu. Hal ini dapat dilihat sebagai kewajiban moral untuk membayar pajak, keyakinan untuk berkontribusi kepada masyarakat dengan membayar pajak. Indikator moralitas pajak antara lain : tingkat partisipasi warga, tingkat kepercayaan, tingkat otonomi daerah atau desentralisasi, faktor demografis, kondisi ekonomi, kebanggaan nasional, faktor pencegah dan sistem perpajakan.

Budaya pajak dalam konsep klasik dimana budaya pajak dari suatu negara sangat berhubungan erat dengan kepribadian yang ditunjukkan oleh evolusi dari suatu sistem perpajakan. Budaya pajak diinvestigasi diantara pembayar pajak dan kantor pajak. Dalam pandangan mereka, permasalahan yang terjadi antara "melakukan tuntunan atas kompensasi dalam hubungannya dengan pelanggaran pekerjaan oleh aparat pajak: dan "untuk memberikan kontribusi terhadap budaya pajak melalui perselisihan pajak". sehingga dalam hal ini, budaya pajak ditandai oleh hubungan antara aparat pajak dengan Wajib Pajak serta pola perilaku yang timbul akibat hubungan tersebut (Ilyas dan Burton, 2007). Ada 3 hal yang mempengaruhi budaya pajak antara lain : hubungan antara aparatur pajak dan wajib pajak, peraturan perpajakan, budaya nasional.

Organization for Economic
Cooperation and Development (OECD) telah mengembangkan seperangkat prinsip-prinsip Good Governance dan dapat diterapkan secara fleksibel sesuai dengan keadaan, budaya, dan tradisi di masing-masing Negara. Prinsipprinsip OECD mencakup transparansi, tanggung jawab, Keadilan, dan akuntabilitas. Transparansi yaitu mewajibkan adanya suatu informasi yang terbuka, tepat waktu, serta jelas dan dapat diperbandingkan yang menyangkut keadaan keuangan, pengelolaan. Tanggung jawab adalah kesesuaian dalam pengelolaan organisasi terhadap peraturan perundang-undangan yang berlaku. Keadilan adanya kesesuaian di dalam pengelolaan menjamin perlindungan dan pemenuhan hak- hak diantaranya para stakeholders yang terkait dengan organisasi. Akuntabilitas menjelaskan peran dan tanggung jawab yang mendukung usaha untuk menjamin penyeimbang kepentingan. Independen menjamin adanya kemandirian dalam melaksanakan wewenang dan tanggung jawab sesuai dengan peraturan yang ada.

Kepatuhan pajak berarti bahwa wajib pajak mempunyai kesediaan untuk memenuhi kewajiban pajaknya sesuai aturan yang berlaku tanpa perlu diadakan pemeriksaan, investigasi seksama peringatan, ataupun ancaman dan penerapan sanksi baik hukum maupun administrasi (Gunadi, 2012). Kepatuhan memenuhi kewajiban perpajakan secara sukarela merupakan tulang punggung self assessment system, dimana Wajib Pajak bertanggung jawab menetapkan sendiri kewajiban perpajakannya dan kemudian secara akurat dan tepat waktu membayar serta melaporkan pajaknya tersebut. Indikator kepatuhan pajak antara lain : kepatuhan formal, kepatuhan material. kepatuhan formal adalah jenis kepatuhan dimana wajib pajak sebatas memenuhi ketentuan pajak. kepatuhan material lebih dalam cakupannya yaitu pemenuhan secara substantif isi dan jiwa ketentuan perpajakan.

\section{Telaah Teoritis dan Pengembangan Hipotesis}

Teori keagenan dimana teori ini mengasumsikan bahwa principal maupun agen merupakan para pelaku ekonomi yang berfikir rasional dan tindakannya semata-mata untuk kepentingan pribadi, akan tetapi mereka menemukan kesulitan dalam membedakan perbedaan atas perferensi, kepercayaan dan informasi. Berbagai konflik kepentingan yang kemudian muncul antara principal dan agen yang disebabkan adanya hubungan keagenan merupakan suatu kontrak dimana pihak principal memerintah orang lain (agen) untuk melakukan suatu jasa atas nama principal serta memberikan wewenang kepada agen untuk memberikan keputusan yang terbaik bagi prinsipalnya (Jensen, 2012). Dalam penelitian ini yang dimaksudkan dengan principal adalah pemerintah/negara yang mempunyai hak untuk menarik pajak pada warganegara, demi kepentingan pembangunan nasional. Besarnya biaya pembangunan yang harus ditanggung 
oleh negara/pemerintah mendorong mereka untuk mengoptimalkan pajak yang dipungut, dengan memungut apa yang memang menjadi haknya berdasarkan aturan dan perundangundangan perpajakan. Agen yang dimaksud dalam artikel ini adalah para wajib pajak yang melakuan self assessment, mereka adalah orang-orang yang seharusnya mengusahakan agar tujuan pemerintah pusat dapat tercapai yaitu mengoptimalkan pemungutan pajak. Dalam proses selanjutnya jika kedua belah pihak mempunyai visi yang sama yaitu mengoptimalkan pajak, maka diharapkan agen akan bertindak sesuai dengan kepentingan principal.

\section{Metode Penelitian}

Metode yang dipergunakan dalam penelitian ini adalah penelitian deskriptif, dimana metode penelitian deskriptif adalah satu metode penelitian yang banyak digunakan pada penelitian yang bertujuan untuk menjelaskan suatu kejadian. Penelitian ini bersifat asosiatif, dilakukan dengan cara menghubungkan variable satu dengan variable yang lain agar dapat mengetahui, menjelaskan dan memprediksi tingkat ketergantungan variable independen dan variable dependen. Dalam pelaksanaannya dilakukan pengumpulan data dengan survei atau kuisioner. Unit analisis yang diteliti adalah individu, yaitu para individu yang merupakan para pengusaha konstruksi yang yang tergabung dalam GAPENSI yang hanya dikumpulkan satu kali pada waktu tertentu disebut juga Crosssectional (Supriyanto, 2011). Analisis data dalam

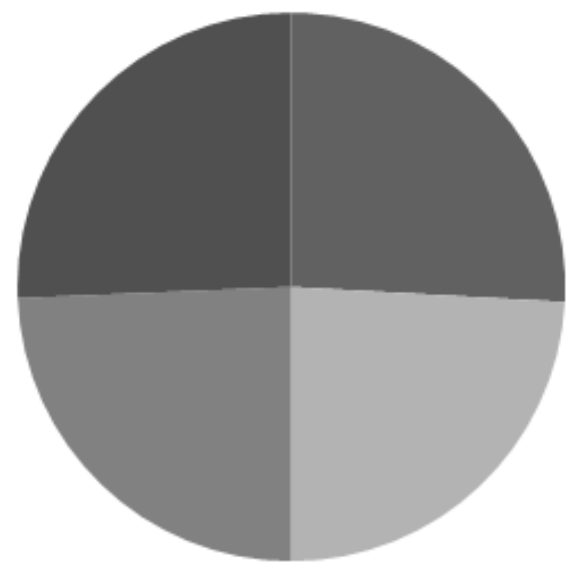

penelitian ini menggunakan metode Partial Least Square (PLS). PLS dapat digunakan pada setiap skala data (nominal, ordinal, interval, rasio) serta syarat asumsi yang lebih fleksibel. PLS juga digunakan untuk mengukur hubungan setiap indikator dengan konstruknya. Selain itu, dalam PLS dapat dilakukan uji bootstrapping terhadap structural model yang bersifat outer model dan inner model. Karena dalam penelitian ini menggunakan indikator untuk mengukur setiap konstruknya, dan juga model pengukuran bersifat struktural, maka diputuskan menggunakan PLS. PLS dapat digunakan untuk tujuan konfirmasi, seperti pengujian hipotesis dan tujuan eksplorasi. Tetapi PLS lebih mengutamakan sebagai eksplorasi daripada konfirmasi. Namun tujuan utama dari PLS adalah untuk menjelaskan hubungan antar konstrak dan menekankan pengertian tentang nilai hubungan tersebut. Hal penting yang harus diperhatikan adalah keharusan adanya teori yang memberikan asumsi untuk menggambarkan model, pemilihan variabel, pendekatan analisis, dan interpretasi hasil (Yamin, 2011).

\section{Hasil Penelitian dan Pembahasan}

Pernyataan keramahan petugas mendapat respon sebesar $25.87 \%$, pernyataan kemampuan petugas pajak dalam permasalahan perpajakan sebesar $24.13 \%$, pernyataan ketanggapan dan kecepatan petugas dalam melayani permasalahan perpajakan mendapat respon sebesar $24.35 \%$, dan perhatian petugas dalam melayani permasalah perpajakan sebesar $25.65 \%$.

Keramahan Petugas Pajak $(25,87 \%)$

Kemampuan Petugas Pajak Dalam

Permasalahan Perpajakan (24,13\%)

Ketanggapan dan Kecepatan Petugas

Pajak Dalam Melayani Permasalahan

Perpajakan (24,35\%)

- Perhatian Petugas Dalam Melayani

Permasalahan Perpajakan (25,65\%)

Gambar 1.

Hubungan antara Aparatur Pajak dan Wajib Pajak 
Pernyataan bahwa ketentuan perpajakan dipublikasikan melalui berbagai media mendapat respon $36 \%$, pernyataan kesesuaian pelaksanaan administrasi perpajakan oleh petugas pajak dengan ketentuan pajak yang berlaku mendapat respon $29 \%$, sedangkan untuk jaminan keadilan wajib pajak dari kepastian hukum perpajakan mendapat respon yang paling tinggi yaitu sebanyak $36 \%$. Seperti terlihat dalam Gambar 2 di bawah ini.

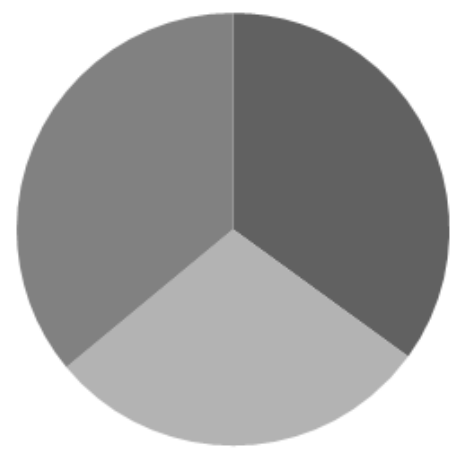

Ketentuan pajak dipublikasikan melalui berbagai Media (35\%)

Kesesuaian pelaksanaan administrasi perpajakan oleh petugas pajak dengan ketentuan pajak yang berlaku (29\%)

- Jaminan keadilan wajib pajak dari kepastian hukum perpajakan (36\%)

Gambar 2.

Gambaran Peraturan Perpajakan

Di Indonesia, budaya pajak dan kepatuhan sedang diupayakan untuk diintensifkan oleh Direktorat Jenderal Pajak melalui program-program perpajakan yang diberlakukan di Indonesia. Pernyataan kesediaan untuk memenuhi ketentuan perpajakan mendapat respon $34.95 \%$,

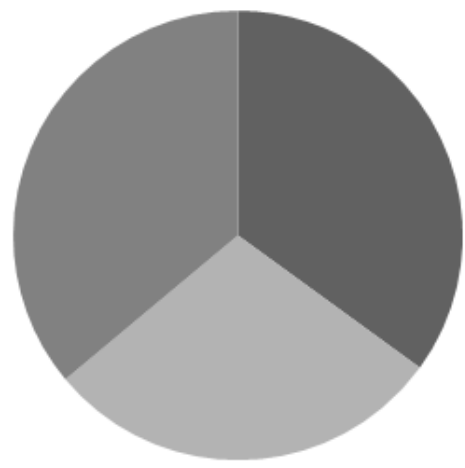

pernyataan kepercayaan atas manfaat dari pajak yang dibayarkan mendapat respon sebesar $28.88 \%$ dan kesadaran untuk membayar dan melaporkan pajak dengan benar mendapat respon paling tinggi yaitu sebesar $36.17 \%$ seperti tergambar dalam gambar 3 di bawah ini.

\section{Gambar 3.}

\section{Gambaran Budaya Nasional}

Good Governance merupakan suatu sistem administrasi yang menginginkan adanya perbaikan pelayananan dan keterbukaan dalam melayani masyarakat pada umumnya dan wajib pajak pada khususnya.Variabel good governance ini memiliki empat subvariabel yang terdiri dari sumber daya manusia, teknologi informasi, struktur organisasi dan Transparansi. Ketiganya memiliki keunggulan masing-masing, untuk subvariabel struktur organisasi terdiri dari dua pernyataan yaitu struktur organisasi KPP menjamin kordinasi yang baik mendapat respon sebesar $16.15 \%$, dan struktur organisasi KPP menjamin pembagian tugas dan beban kerja yang merata mendapat respon sebesar $16.62 \%$. Teknologi informasi dengan pernyataan fasilitas dan sarana pendukung pelayanan yang memadai mendapat respon sebesar $17.25 \%$. Sumber daya manusia dengan pernyataan kecepatan pelayanan yang mendukung wajib pajak mendapat respon sebesar $17.36 \%$, petugas memberikan pelayanan yang cukup kompeten 
mendapat respon sebesar $15.95 \%$. Subvariabel Transparansi yaitu pernyataan adanya transparansi prosedur dan biaya mendapat respon sebesar $17.23 \%$. dan dapat dilihat dalam gambar 4 di bawah ini.
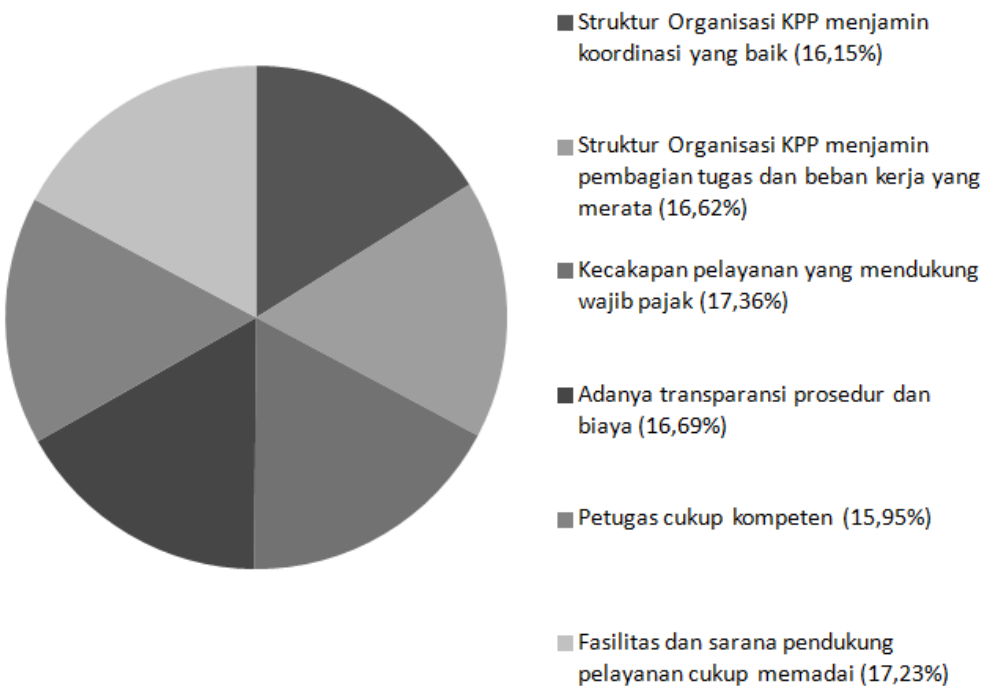

Gambar 4.

Tanggapan Responden terhadap Good Governance

Kepatuhan pajak dapat didefinisikan sebagai suatu keadaan dimana wajib pajak memenuhi semua kewajiban perpajakan dan melaksanakan hak perpajakannya. Kepatuhan pajak dari wajib pajak diukur melalui dua indikator yaitu kepatuhan formal dan kepatuhan material. Kepatuhan formal adalah

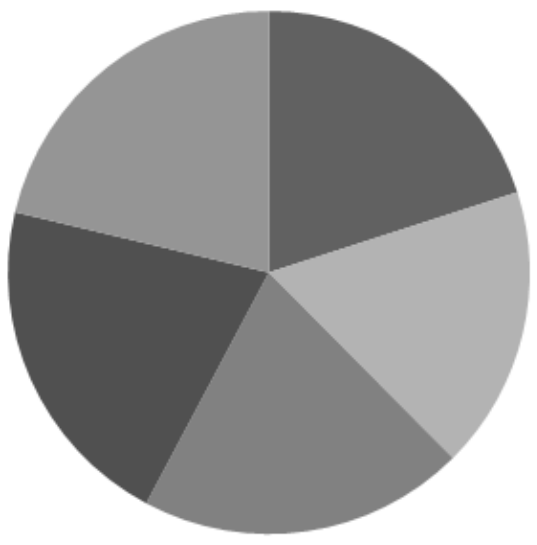

suatu keadaan dimana wajib pajak memenuhi kewajiban perpajakan secara formal sesua dengan ketentuan formal dalam undangundang perpajakan. Gambaran mengenai kepatuhanformal dapat dilihat pada gambar 5 seperti di bawah ini.

Gambar 5.

Gambaran Indikator Kepatuhan Formal

Dalam kepatuhan formal mendaftarkan diri karena kesadaran mendapat respon sebesar $20.03 \%$, mendaftarkan diri karena takut hukum mendapat respon sebesar $17.52 \%$, menyampaikan SPT tepat waktu mendapat respon sebesar $20.24 \%$, membayar pajak tepat pada waktunya mendapat respon sebanyak $20.93 \%$. dan melaporkan pajak tepat waktu mendapat respon yang paling tinggi yaitu $21.28 \%$. hal ini terjadi karena para wajib banyak tidak mau dikenakan sanksi perpajakan dikarenakan terlambat. 
Kepatuhan material adalah suatu keadaan dimana wajib pajak secara substantive/ hakikat memenuhi semua ketentuan materiil perpajakan yakni sesuai isi dan jiwa undangundang perpajakan. Untuk subvariabel kepatuhan material terdiri dari pernyataan menghitung sendiri SPT yang mendapat respon $21.08 \%$, kesesuaian jumlah kewajiban pajak yang harus dibayar dengan perhitungan sendiri

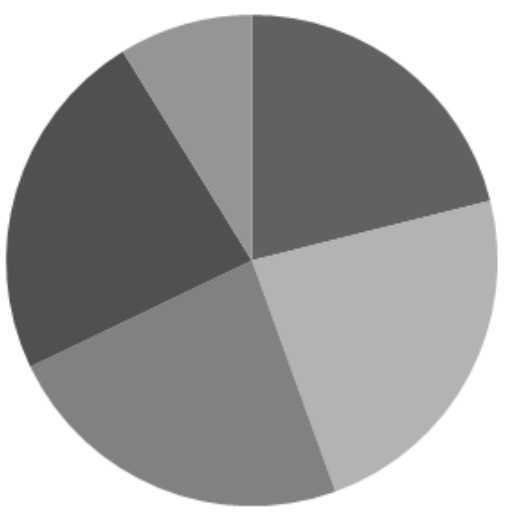

mendapat respon cukup tinggi sebesar $23.40 \%$, peran konsultan dalam menentukan jumlah pajak mendapat respon yang sama besar yaitu sebesar $23.40 \%$ juga, mempercayai konsultan dalam menentukan jumlah pajak mendapat respon $23.40 \%$, dan tunggakan pajak negara hanya mendapat respon yang sangat kecil yaitu sebesar $8.80 \%$. Gambaran selengkapnya disajikan pada gambar 6 di bawah ini.

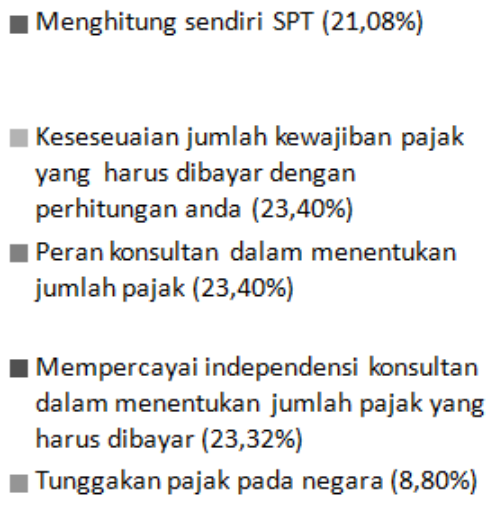

- Tunggakan pajak pada negara $(8,80 \%)$

Gambar 6.

Gambaran Indikator Kepatuhan Material

Model measurement merupakan model yang memspesifikasi hubungan antara variabel laten dengan indikator-indikatornya atau dapat dikatakan bahwa outer model mendefinisikan bagaimana setiap indikator berhubungan dengan variable konstruknya. Ada empat kontsruk laten yaitu Tax Morale, Good Governance, Tax Culture dan Tax Compliance. Indikator pada konstruk Tax Morale, Tax Culture dan Tax Compliance bersifat formatif sedangkan indikator pada konstruk Good Governance bersifat reflektif.

Variabel good governance menunjukkan validitas konvegen untuk indikator transparansi 0.9281 , sumber daya manusia 0.8903 , struktur organisasi 0.9231 dan teknologi informasi 0.9391 dapat dikatakan bahwa indikator memiliki validitas konvergen yang baik karena telah melampaui batasan nilai loading $>0.5$. Kemudian dilakukan uji validitas diskiminan dimana model pengukuran dinilai berdasarkan pengukuran cross loading dengan konstrak. Jika korelasi konstrak dengan setiap indikatornya lebih besar daripada ukuran konstrak lainnya, maka konstrak laten memprediksi indikatornya lebih baik daripada konstrak lainnya. Hasilnya menunjukkan bahwa subvariabel transparansi, Sumber Daya
Manusia, Struktur Organisasi dan Teknologi informasi merupakan indikator yang pas sebagai konstrak dari good governance, karena memiliki nilai paling besar daripada terhadap variabel lain. Yaitu terdiri dari transparansi 0.9281 , sumberdaya manusia 0.8903 , struktur organisasi 0.9231 , dan teknologi informasi 0,9391. Dan kemudian ditambah variabel good governance ini telah mencapai validitas diskriminan yang baik. Hal itu disebabkan karena nilai AVE $>0.5$ yaitu sebesar 0.8470 . Selain itu dengan tercapainya angka $>0.8$ yaitu 0.9567 untuk composite reliability. Maka dapat dikatakan bahwa konstrak memiliki reliabilitas yang tinggi. Untuk pengujian dengan PLS, uji reliabilitas diperkuat dengan adanya cronbach alpha dimana konsistensi setiap jawaban diujikan dengan dicapainya Cronbach alpha $\alpha$ $\geq 0.5$ yaitu 0.9396 .

Dalam pengukuran formatif, untuk mengukur kualitas model formatif reliabilitas indikator dievaluasi dengan melihat nilai weight indikator $>0.2$ atau signifikan uji t. Kriteria signifikansi uji $\mathrm{t}$ dengan nilai alpha $5 \%$ nilai $\mathrm{t}$ $=1.96$ dan $10 \%$ nilai $\mathrm{t}=1.640$ namun apabila hanya indikator weight yang menunjukkan signifikan maka indikator tersebut masih bisa dipertahankan (Hair, 2011). Hasil uji realibilitas 
pada konstruk laten dengan indikator formatif adalah sebagai berikut untuk variable moralitas pajak, sub variable yang mendukungnya adalah faktor demografis dengan weight 0.2922 dan t-statistik 1.525, untuk tingkat kepercayaan dengan weight 0.2126 dan t-statistik 1.602 , untuk tingkat otonomi daerah dengan 0.3813 dan t-statistik 1.992, untuk tingkat partisipasi warga Negara dengan weight 0.2271 dan $\mathrm{t}$ statistic 1.634. Hasil uji reliabilitas variable budaya pajak dengan subvariabel budaya nasional dengan weight 0.310 dan $\mathrm{t}$ statistic 1.598, hubungan aparatur dan warga Negara dengan weight 0.485 dan t-statistic 2.332 , dan peraturan pemerintah dengan weight 0.261 dan t-statistic 1.301. Dan hasil uji reliabilitas untuk kepatuhan pajak dengan subvariabel kepatuhan formal dengan weight 0.6781 dan t-statistic 5.155 dan kepatuhan material dengan weight 0.3822 dan t-statistic 2.621.

Kemudian dilakukan pengujian relevansi prediksi (Q2) bertujuan untuk mengukur seberapa baik nilai observasi yang dihasilkan oleh model dan juga estimasi parameternya menunjukkan hasil sebesar 0.8470 lebih besar dari nol yang menunjukkan bahwa model memiliki relevansi prediksi yang baik.

Inner model merupakan model yang menspesifikasi hubungan antar variabel laten atau bisa dikatakan inner modelmenggambarkan antar variabel laten berdasarkan substansi teori. Menilai inner model adalah mengevaluasi hubungan antar variabel laten seperti yang telah dihipotesiskan dalam penelitian. nilai R-square untuk kepatuhan pajak menunjukkan nilai sebesar 0.699. Nilai R-square ini berarti menunjukan bahwa variabel moralitas pajak, budaya pajak, dan Good Governance, mampu menjelaskan varians kepatuhan pajak sebesar $69.9 \%$ (0.699 x 100\%). Kemampuan menjelaskan dengan nilai R-square 0.699 masuk kategori nilai R-square kuat.

Dalam hipotesis pertama, variabel moralitas pajak merupakan variabel laten eksogen yang berpengaruh terhadap kepatuhan pajak sebagai variabel endogen. Dengan membandingkan nilai uji $\mathrm{t}$ dengan t-tabel $(\alpha=0.05)$ sebesar 1.96 maka diperolah kesimpulan bahwa semua taksiran parameter pada diagram jalur tersebut adalah signifikan karena nilai t-value $>0,05$. Hal ini berarti terdapat pengaruh moralitas pajak terhadap kepatuhan pajak, dimana tinggi rendahnya kepatuhan pajak dipengaruhi secara nyata dan positif oleh tinggi rendahnya moralitas pajak. Besar pengaruh moralitas pajak terhadap kepatuhan pajak adalah sebesar $36.55 \%$ dimana kontribusi terbesar diperoleh dari dimensi tingkat otonomi daerah yaitu sebesar $38.13 \%$ dan kontribusi terkecil diperoleh dari Tingkat Kepercayaan sebesar 21.26\%.

Literatur perpajakan menunjukkan bahwa fenomena kerelaan wajib pajak untuk melakukan kewajiban perpajakannya sering disebut sebagai "puzzel of tax complience" (Torgler, 2007). Hal ini karena banyaknya faktor yang berusaha menjelaskan pertanyaan mendasar mengapa wajib pajak membayar pajak. Norma sosial dari kepatuhan pajak adalah moralitas pajak dan moralitas pajak inilah yang menyebabkan wajib pajak rela dan patuh untuk melakukan kewajiban perpajakannya. Hasil riset dan penelitian dewasa ini telah banyak dilakukan untuk mendukung hubungan antara moralitas pajak terhadap kepatuhan pajak. Moralitas pajak individu dipengaruhi secara langsung oleh persepsi wajib pajak akan adanya pemenuhan barang dan jasa publik oleh Negara (James dan Gomez, 2008). Lebih lanjut, semakin tinggi kemampuan terjadinya pelanggaran fiskal, dalam artian terdapat ekonomi biaya tinggi untuk melakukan kewajiban perpajakan, maka akan semakin rendah motivasi instrinsik individu untuk membayar pajak. Hal ini sejalan dengan hasil penelitian dimana pemenuhan barang dan jasa publik serta ekonomi biaya tinggi merupakan bagian dari indikator tingkat kepercayaan masyarakat terhadap pemerintah. Namun, indikator tersebut ternyata memiliki pengaruh yang paling rendah terhadap moralitas pajak dan kepatuhan di Bogor.

Dalam hipotesis kedua, variabel budaya pajak merupakan variabel laten eksogen yang berpengaruh terhadap kepatuhan pajak sebagai variabel laten endogen. Dengan membandingkan nilai uji $t$ dengan nilai t-tabel $(\alpha=0.05)$ sebesar 1.96 maka diperoleh kesimpulan bahwa semua taksiran parameter pada diagram jalur tersebut adalah signifikan karena nilai t-value $>0.05$. hal ini berarti terdapat pengaruh budaya pajak terhadap kepatuhan pajak, dimana tinggi rendahnya moralitas pajak dipengaruhi secara nyata dan positif oleh tinggi rendahnya budaya pajak. Besar pengaruh budaya pajak terhadap kepatuhan pajak sebesar $23.52 \%$, dimana kontribusi terbesar diperoleh dari dimensi Hubungan antara Aparatur Pajak 
dan Wajib Pajak yaitu sebesar $48.48 \%$ dan kontribusi terkecil diperoleh dari Peraturan Perpajakan yaitu sebesar 26.15\%.

Konsep budaya pajak merupakan keseluruhan interaksi formal dan informal dalam suatu institusi yang menghubungkan sistem perpajakan nasional dengan praktik hubungan antara aparatur pajak dengan wajib pajak, dimana secara historis melekat dengan budaya nasional, termasuk ketergantungan dan ikatan yang terbentuk akibat interaksi yang berkelanjutan.

Variabel budaya pajak memiliki pengaruh yang lebih kecil (23.52\%) terhadap kepatuhan pajak dibandingkan dengan moralitas pajak (36.55\%). Hal ini dapat dikarenakan adanya sikap apatis baik dari pemerintah maupun wajib pajak untuk memajukan budaya pajak. Budaya pajak adalah seperangkat interaksi baik meliputi wajib pajak, pemerintah, budaya nasional maupun perangkat aturan perpajakannya. Wajib pajak umumnya merasa bahwa pajak adalah sebuah beban (burden), dan insentif dari kontribusi pembayaran pajak dilakukan tidak dapat langsung dinikmati dimana tanggung jawab pemerintah untuk memberikan pemenuhan barang dan jasa publik yang berkualitas juga masih diragukan. (Pandey, 2003). Sedangkan pemerintah umumnya mengeluarkan kebijakan dan peraturan tanpa melakukan sosialisasi dan publikasi yang berkelanjutan, sehingga terdapat gap antara pemerintah dan wajib pajak dalam hal ini.

Terdapat kecenderungan budaya dalam masyarakat untuk meloloskan diri dari pembayaran pajak karena membayar pajak adalah suatu aktivitas yang tidak lepas dari kondisi behavior wajib pajak itu sendiri. Karenanya, untuk mengetahui kepatuhan wajib pajak dalam melaksanakan kewajibannya maka fungsi pengawasan sekaligus pembinaan harus diefektifkan karena ini merupakan konsekuensi dari pemberian kepercayaan kepada wajib pajak (self-assesment), sedangkan dalam membina wajib pajak tidak patuh maka tax-enforcement harus ditegakkan. Pilar-pilar penegakkan hukum pajak harus dijaga dengan baik melalui peraturan dan kebijakan pajak yang tepat dan tersosialisasi secara berkesinambungan.

Dalam hipotesis ketiga, variabel good governance merupakan variabel laten eksogen yang berpengaruh terhadap kepatuhan pajak sebagai variabel laten endogen. Dengan membandingkan nilai uji $\mathrm{t}$ dengan nilai t-tabel $(\alpha=0.05)$ sebesar 1.96 maka diperoleh kesimpulan bahwa semua taksiran parameter pada diagram jalur tersebut adalah signifikan karena nilai t-value $>0.05$. hal ini berarti terdapat pengaruh good governance erhadap kepatuhan pajak, dimana tinggi rendahnya moralitas pajak dipengaruhi secara nyata dan positif oleh tinggi rendahnya budaya pajak. Besar pengaruh good governance terhadap kepatuhan pajak sebesar $29.83 \%$, dimana kontribusi terbesar diperoleh dari dimensi Teknologi Informasi sebesar $28.63 \%$ dan kontribusi terkecil diperoleh dari Sumber Daya sebesar 26.39\%.

$\begin{array}{ccc}\text { Teknologi } & \text { informasi } & \text { dalam } \\ \text { sebagai pendukung pemerintah } & \text { dalam }\end{array}$ aktifitas perpajakan, baik itu dari perspektif pelayanan,hingga peningkatan lajunya pembangunan, merupakan salah satu pendorong dari tujuan good governance. Sehingga dapat dibangun jaringan kerja sama didasarkan atas hubungan yang partisipatif, transparan, dan responsif antar pilar-pilar good governance. Penggunaan teknologi informasi oleh pemerintah, yang memungkinkan pemerintah untuk mentransformasikan hubungan dengan masyarakat, dunia bisnis dan pihak yang berkepentingan dapat membantu pemerintah dan penyediaan pelayanan publik agar lebih baik dan berorientasi pada pelayanan masyarakat.

Hasil pengujian menunjukkan terdapat pengaruh variabel Good Governance terhadap empat indikator yaitu sumber daya manusia, teknologi informasi, struktur organisasi dan transparansi. Hasil ini membuktikan bahwa Teknologi Informasi menjadi sangat penting dalam pelaksanaan Good Governance. Teknologi informasi dalam sebagai pendukung pemerintah dalam aktifitas perpajakan, baik itu dari perspektif pelayanan, hingga peningkatan lajunya pembangunan, merupakan salah satu pendorong dari tujuan good governance. Sehingga dapat dibangun jaringan kerja sama didasarkan atas hubungan yang partisipatif, transparan, dan responsif antar pilar-pilar good governance. Penggunaan teknologi informasi oleh pemerintah, yang memungkinkan pemerintah untuk mentransformasikan hubungan dengan masyarakat, dunia bisnis dan pihak yang berkepentingan dapat membantu pemerintah dan penyediaan pelayanan publik agar lebih baik dan berorientasi pada pelayanan masyarakat. Secara konseptual, teknologi informasi ini menciptakan interaksi 
yang ramah dan murah antara pemerintah dan masyarakat, karena dalam prakteknya teknologi informasi sebagai fasilitas dan komunikasi guna pelaksanaan pemerintah yang efisien dan murah, dengan meningkatkan pelayanan masyarakat dengan cara menyediakan sarana publik sehingga mudah mendapatkan informasi, dan menciptakan pemerintahan yang baik dan terwujudnya pemerintahan yang lebih bertanggung jawab bagi warganya. Dengan adanya teknologi informasi ini akan tercipta pemerintahan yang lebih baik, karena proses pelayanan yang lebih transparan, terjadi kontrol masyarakat yang lebih kuat, dan pengawasan yang bersifat lekat waktu, Berkurangnya praktek-praktek korupsi, karena komputer tidak memiliki sifat bawaan perilaku yang korup, Tata hubungan yang lebih ramping untuk terlaksananya pemerintah yang lebih baik, peningkatan efisiensi pemerintah di semua proses untuk menghadapi pemborosan belanja sektor publik atau inefisiensi dalam berbagai proses, akan terjadi efisisensi dalam skala ruang dan waktu, struktur dan organisasi informasi yang tersistematisasi dan peningkatan manajemen dari sumber daya baik dari sisi peningkatan bidang kendali maupun sumber daya organisasinya.

Pengaruh signifikan good governance terhadap transparansi adalah prinsip yang menjamin akses atau kebebasan bagi setiap orang untuk memperoleh informasi tentang penyelenggaraan pemerintahan, yakni informasi tentang kebijakan, proses pembuatan dan pelaksanaannya, serta hasil-hasil yang dicapai. Selain itu juga merupakan informasi mengenai setiap aspek kebijakan pemerintah yang dapat dijangkau oleh publik. Keterbukaan informasi diharapkan akan menghasilkan persaingan politik yang sehat, toleran, dan kebijakan dibuat berdasarkan pada preferensi publik. Prinsip ini memiliki 2 aspek, yaitu komunikasi publik oleh pemerintah, dan hak masyarakat terhadap akses informasi. Keduanya akan sangat sulit dilakukan jika pemerintah tidak menangani dengan baik kinerjanya. Manajemen kinerja yang baik adalah titik awal dari transparansi.

Komunikasi publik menuntut usaha afirmatif dari pemerintah untuk membuka informasi maupun aktivitasnya yang relevan. Transparansi harus seimbang dengan kebutuhan akan kerahasiaan lembaga maupun informasiinformasi yang mempengaruhi hak privasi individu. Karena pemerintahan menghasilkan data dalam jumlah besar, maka dibutuhkan petugas informasi professional, bukan untuk membuat dalih atas keputusan pemerintah, tetapi untuk menyebarluaskan keputusankeputusan yang penting kepada masyarakat serta menjelaskan dari setiap kebijakan tersebut.

Peran media juga sangat penting bagi transparansi pemerintah, baik sebagai sebuah kesempatan untuk berkomunikasi pada publik maupun menjelaskan berbagai informasi yang relevan, juga sebagai "watchdog" atas berbagai aksi pemerintah dan perilaku menyimpang dari para aparat birokrasi. Jelas, media tidak akan dapat melakukan tugas ini tanpa adanya kebebasan pers, bebas dari intervensi pemerintah maupun pengaruh kepentingan bisnis.

Keterbukaan membawa konsekuensi adanya kontrol yang berlebih-lebihan dari masyarakat dan bahkan oleh media massa. Karena itu, kewajiban akan keterbukaan harus diimbangi dengan nilai pembatasan, yang mencakup kriteria yang jelas dari para aparat publik tentang jenis informasi apa saja yang mereka berikan dan pada siapa informasi tersebut diberikan. Secara ringkas dapat disebutkan bahwa, prinsip transparasi dapat diukur melalui sejumlah indikator seperti : menjamin sistem keterbukaan dan standarisasi dari semua proses-proses pelayanan publik, memfasilitasi pertanyaan-pertanyaan publik tentang berbagai kebijakan dan pelayanan publik, maupun proses-proses didalam sektor publik, memfasilitasi pelaporan maupun penyebaran informasi maupun penyimpangan tindakan aparat publik didalam kegiatan melayani.

Keterbukaan pemerintah atas berbagai aspek pelayanan publik, pada akhirnya akan membuat pemerintah menjadi bertanggung gugat kepada semua stakeholders yang berkepentingan dengan proses maupun kegiatan dalam sector publik. Pengaruh signifikan good governance terhadap perubahan struktur organisasi. Masalah utama dalam struktur organisasi adalah meyakinkan diri bahwa pengambilan keputusan dan akuntabilitas semua pihak yang berkepentingan terhadap organisasi mempunyai informasi dan pengetahuan yang relevan mengambil keputusan yang baik dan benar serta adanya insentif sepadan yang menggunakan informasi secara produktif dan terpercaya, karena perubahan lingkungan yang berpengaruh terhadap perubahan struktur 
organisasi, biaya, dan manfaat langsung maupun tidak langsung harus dianalisis secara cermat dan hati-hati. Dengan adanya Good Governance tersebut maka efektifitas fungsi dalam struktur oraganisasi dapat berjalan sebagaimana mestinya. Kemudian dalam rangka pelaksanaan Good Governance, struktur organisasi modern dapat melakukan : Kesadaran yang tinggi terhadap tingkat urgensi, Kerja sama tim yang baik dalam tatanan staf dan manajemen, bisa menciptakan dan mengomunikasikan visi, misi, dan program dengan baik, pemberdayaan semua karyawan dengan memperhatikan minat dan bakat, memberikan delegasi wewenang dengan efektif, mengurangi ketergantungan yang tidak perlu, dan mengembangkan budaya organisasi yang adaptif dan penggunaan analisis kinerja.

Pengaruh signifikan good governance terhadap sumber daya manusia. Kualitas sumber daya manusia dapat diamati dari kemampuan profesionalitas sesuai dengan bidang tugas yang menjadi tanggung jawabnya. Beberapa faktor yang dapat mempengaruhi sumber daya manusia antara lain tingkat pendidikan, pelatihan, dan penempatan pegawai dalam jabatan. Dalam pelaksanaan tugas, prinsip-prinsip yang terkandung dalam good governance merupakan acuan bagi terselenggaranya pemerintahan yang dapat bersinergi dengan masyarakat, dalam rangka pelaksanaan pelayanan publik yang optimal. sikap aparatur pemerintah yang melakukan penyimpangan dalam pelaksanaan administrasi dan manajemen pemerintahan dapat menyebabkan hasil-hasil pembangunan dan pelayanan publik sebagian besar tidak sesuai dengan yang diharapkan dan direncanakan. Maka dari itu keberadaan aparatur yang berkualitas akan sangat ditentukan oleh kemampuan aparatur yang bersangkutan untuk mengimplementasikan prinsip-prinsip good governance dalam penyelenggaraan pelayanan publik.

Dari variable good governance yang paling besar mempengaruhi hasilnya adalah teknologi informasi. Penerapan good governance akan lebih mengoptimalkan peranan informasi teknologi dalam berbagai bidang, karena pada dasarnya pemanfaatan teknologi informasi secara umum bertujuan untuk memudahkan pelaksanaan proses bisnis dan meningkatkan kemampuan kompetitif. Selain itu dengan adanya informasi teknologi kegiatan operasional organisasi dapat dilaksanakan lebih mudah, cepat, efisien dan efektif juga telah menawarkan banyak peluang kepada organisasi untuk meningkatkan dan mentransformasi produksi, pelayanan, pasar, proses kerja, dan hubungan-hubungan bisnis. Namun demikian masih banyak perusahaan dan organisasi yang menerapkan prinsip dan cara kerja good governance belum mengoptimalkan peranan informasi teknologi dalam melaksanaannya padahal teknologi informasi tersebut sangat dibutuhkan untuk dapat menghilangkan kekurangan atau kelemahan pada pelaksanaan kegiatan operasional dan pelayanan kepada customer yang menjadi penghambat kinerja dan inovasi proses dan kegiatan bisnis perusahaan juga Peningkatan kinerja, keunggulan kompetitif, dan pencapaian tujuan dan sasaran organisasi dapat dicapai melalui penerapan informasi teknologi dan good governance.

Terdapat pengaruh tingkat partisipasi warga negara terhadap moralitas pajak, warga negara Indonesia yang mayoritas muslim sudah terbiasa dengan mengeluarkan sumbangan wajib keagamaan hal itu menjadi landasan mereka untuk berpartisipasi dalam melakukan kewajiban perpajakan pada setiap tahunnya, karena menurut mereka sebagai pemeluk agama yang taat ada sebagian rejeki milik orang lain yang berada di dalam harta yang diperolehnya. Pemikiran seperti itu juga diterapkan dalam kegiatan perpajakannya, yang berpendapat bahwa dalam harta yang diperolehnya mereka dengan sukarela menyisihkannya untuk kebaikan orang lain dengan cara mendukung pemerintah dalam hal pembangunan negara ini. Maka dari itu dengan adanya partisipasi warga negara ini maka akan terbentuk moralitas pajak yang mendukung jalannya pembangunan.

Terdapat pengaruh tingkat kepercayaan terhadap terbentuknya moralitas pajak, dalam penelitian ini ditemukan bahwa tingkat kepercayaan terhadap pemerintah menduduki posisi yang tertinggi, warga negara termotivasi untuk melakukan kewajiban perpajakannya karena tingkat kepercayaan mereka terhadap pemerintah yang mereka yakini dengan adanya pendapatan yang berasal dari pajak ini akan membantu dalam pembangunan. Selain itu tingkat kepercayaan ini juga terdiri dari kepercayaan terhadap hukum yang berlaku, bahwa hukum yang ada di negeri ini dapat ditegakkan, juga percaya pada sistem peradilan. Sehingga setiap bentuk tindak kejahatan akan mendapat ganjaran yang setimpal. Terbukti dengan adanya beberapa contoh kejahatan 
yang terjadi saat ini yang kemudian diberikan hukuman yang cukup berat. Dengan adanya contoh-contoh kasus seperti itu menjadikan efek jera terhadap pelaku kejahatan berkerah putih juga memberikan citra yang baik bagi pemerintah bahwa pemerintah tidak main-main dalam melakukan kewajibannya, sehingga amanah dari rakyat yang berupa pembayaran pajak dapat dipergunakan untuk rakyat juga dan tidak disalahgunakan oleh orang-orang yang berniat memperkaya diri sendiri.

Pengaruh otonomi daerah atau desentralisasi terhadap moralitas pajak yaitu dengan adanya kebebasan dalam mengatur pemerintahan sendiri mendorong warga untuk lebih meningkatkan sikap moralitas pajak. Karena menurut mereka apabila ada kebebasan untuk mangatur pemerintahan sendiri maka secara otomatis dapat memantau penerimaan dan pengluaran pemerintah yang diperoleh dari pajak, sehingga dapat meningkatkan motivasi instrinsik untuk melakukan kewajiban perpajakannya. Selain itu dengan adanya otonomi daerah akan terjadi hubungan yang lebih intensif antara Wajib Pajak dengan birokrat, serta dalam pengelolan pajak yang mereka bayarkan.

Pengaruh faktor kebanggaan terhadap moralitas pajak yaitu dengan cintanya seseorang terhadap Indonesian akan menciptakan perasaan bangga menjadi warga negara, sehingga faktor tersebut dapat memotivasi seseorang untuk selalu melakukan hal yang baik bagi negaranya, juga memastika bahwa negaranya dapat berjalan dengan baik.

Pengaruh faktor demografis terhadap moralitas pajak. Usia, pendidikan, jenis kelamin dan status perkawinan merupakan hal yang bisa menjadi pendorong untuk menimbulkan sikap moralitas pajak. Semakin dewasa usia seseorang maka semakin tinggi kesadaran seseorang untuk melakukan kewajiban perpajakannya. Selain itu pendidikan juga dapat menumbuhkan motivasi instrinsik seseorang untuk melakukan kewajiban perpajakannya karena semakin banyak ilmu pengetahuan yang diterima maka akan lebih mengerti manfaat pajak bagi negara. Dari penelitian ini juga dapat diketahui bahwa wanita memiliki moralitas pajak yang lebih tinggi, meskipun ada wanita yang berperan hanya sebagai istri maka mereka akan mendorong suami untuk melakukan kewajiban perpajakannya. Sedangkan untuk status perkawinan, banyak wajib pajak yang mau melakukan perpajakannya ketika sudah menikah, hal ini disebabkan dengan status perkawinan ada bagian dari pajak yang harus dibayarkan telah dipisahkan dari pendapatan tidak kena pajak, yang menyebabkan ada bagian dari pendapatan itu dapat disimpan.

Hubungan antara aparatur pajak dengan Wajib Pajak dapat berupa hubungan yang bersifat administratif dalam artian berkaitan dengan tugas dan tanggung jawab aparatur pajak terhadap wajib pajaknya, maupun hubungan yang bersifat informal. Beberapa hal yang termasuk di dalamnya yaitu keramahan petugas, pernyataan kemampuan petugas pajak dalam permasalahan perpajakan, ketanggapan dan kecepatan petugas dalam melayani permasalahan perpajakan dan perhatian petugas dalam melayani permasalahan perpajakan.

Peraturan pajak yang kondusif akan mendukung terciptanya budaya pajak yang positif pula. Ketentuan perpajakan dipublikasikan melalui berbagai media, kesesuaian pelaksanaan administrasi perpajakan oleh petugas pajak dengan ketentuan pajak yang berlaku sedangkan untuk jaminan keadilan wajib pajak dari kepastian hukum perpajakan hal-hal tersebutlah yang bisa mempengaruhi faktor instrinsik wajib pajak.

Pengaruh budaya nasional terhadap budaya pajak. Aspek mendasar yang menjadi indikator dari budaya nasional yang memiliki kecenderungan terhadap budaya pajak antara lain permasalahan disiplin bangsa. Di Indonesia, budaya pajak dan kepatuhan sedang diupayakan untuk diintensifkan oleh Direktorat Jenderal Pajak melalui program-program perpajakan yang diberlakukan di Indonesia. Budaya ini tercipta karena adanya kepercayaan atas manfaat dari pajak yang dibayarkan.

Untuk subvariabel moralitas pajak yang terdiri dari delapan faktor yang mempengaruhi moralitas pajak hanya empat yang mempunyai pengaruh signifikan, yaitu faktor demografis, faktor kebanggaan, tingkat kepercayaan, dan tingkat partisipasi warga negara. Pengaruh moralitas pajak terhadap kepatuhan pajak, dimana tinggi rendahnya kepatuhan pajak dipengaruhi secara nyata dan positif oleh tinggi rendahnya moralitas pajak. Hal ini karena banyaknya faktor yang berusaha menjelaskan pertanyaan mendasar mengapa wajib pajak membayar pajak. Norma sosial dari kepatuhan pajak adalah moralitas pajak dan moralitas pajak inilah yang menyebabkan 
wajib pajak rela dan patuh untuk melakukan kewajiban perpajakannya. Hasil riset dan penelitian dewasa ini telah banyak dilakukan untuk mendukung hubungan antara moralitas pajak terhadap kepatuhan pajak. Penelitian yang dilakukan di bogor ini juga sejalan dengan hasil penelitian sebelumnya yang menyatakan bahwa salah satu faktor yang mempengaruhi kepatuhan pajak yaitu faktor demografis yang berupa kondisi keuangan dan pendapatan wajib pajak.

Hasil dari penelitian ini membuktikan bahwa faktor demografis, faktor kebanggaan, tingkat kepercayaan, dan tingkat partisipasi warga negara berperan penting dalam meningkatkan kepatuhan pajak, hal ini dikarenakan keempat variabel tersebut akan memberikan motivasi instrinsik untuk melakukan kewajiban perpajakannya. Hal ini sejalan dengan penelitian sebelumnya yang juga mengungkapkan bahwa partisipasi warga negara merupakan hasil yang dicapai pemerintah untuk pembangunan. Dengan adanya partisipasi warga negara yang baik maka pembangunan yang direncanakan oleh pemerintah dapat tercapai sementara apabila partisipasi warga negara kurang baik maka pembangunan yang direncanakan pemerintah tidak akan tercapai bahkan gagal.

Konsep budaya pajak merupakan keseluruhan interaksi formal dan informal dalam suatu institusi yang menghubungkan sistem perpajakan nasional dengan praktik hubungan antara aparatur pajak dengan wajib pajak, dimana secara historis melekat dengan budaya nasional, termasuk ketergantungan dan ikatan yang terbentuk akibat interaksi yang berkelanjutan. Variabel budaya pajak memiliki pengaruh yang lebih kecil $(23.52 \%)$ terhadap kepatuhan pajak dibandingkan dengan moralitas pajak (36.55\%). Hal ini dapat dikarenakan adanya sikap apatis baik dari pemerintah maupun wajib pajak untuk memajukan budaya pajak. Wajib pajak umumnya merasa bahwa pajak adalah sebuah beban, dan insentif dari kontribusi pembayaran pajak dilakukan tidak dapat langsung dinikmati dimana tanggung jawab pemerintah untuk memberikan pemenuhan barang dan jasa publik yang berkualitas juga masih diragukan. Sedangkan pemerintah mengeluarkan kebijakan dan peraturan tanpa melakukan sosialisasi dan publikasi yang berkelanjutan, sehingga terdapat gap antara pemerintah dan wajib pajak.
Terlepas dari perbandingan pengaruh budaya pajak yang lebih kecil dibandingkan moralitas pajak, budaya pajak tetap merupakan variabel yang mampu menjelaskan kepatuhan pajak. Terdapat kecenderungan budaya dalam masyarakat untuk meloloskan diri dari pembayaran pajak karena membayar pajak adalah suatu aktivitas yang tidak lepas dari kondisi behavior wajib pajak itu sendiri. Karenanya, untuk mengetahui kepatuhan wajib pajak dalam melaksanakan kewajibannya maka fungsi pengawasan sekaligus pembinaan harus diefektifkan karena ini merupakan konsekuensi dari pemberian kepercayaan kepada wajib pajak, sedangkan dalam membina wajib pajak tidak patuh maka tax-enforcement harus ditegakkan. Pilar-pilar penegakkan hukum pajak harus dijaga dengan baik melalui peraturan dan kebijakan pajak yang tepat dan tersosialisasi secara berkesinambungan. Peraturan pajak disusun tidak hanya untuk kepentingan negara saja, namun juga harus mempertimbangkan budaya nasional sebagai dasar historis bangsa.

Teknologi informasi sebagai pendukung pemerintah dalam aktifitas perpajakan, baik itu dari perspektif pelayanan, hingga peningkatan lajunya pembangunan, merupakan salah satu pendorong dari tujuan good governance. Sehingga dapat dibangun jaringan kerja sama didasarkan atas hubungan yang partisipatif, transparan, dan responsif antar pilar-pilar good governance. Penggunaan teknologi informasi oleh pemerintah, dapat mentransformasikan hubungan dengan masyarakat, dunia bisnis dan pihak yang berkepentingan dapat membantu dan penyediaan pelayanan publik agar lebih baik dan berorientasi pada pelayanan masyarakat. Secara konseptual, teknologi informasi ini menciptakan interaksi yang ramah dan murah antara pemerintah dan masyarakat, karena dalam prakteknya teknologi informasi sebagai fasilitas dan komunikasi guna pelaksanaan pemerintah yang efisien dan murah, dengan meningkatkan pelayanan masyarakat dengan cara menyediakan sarana publik sehingga mudah mendapatkan informasi, dan menciptakan terwujudnya pemerintahan yang baik dan bertanggung jawab bagi warganya. Karena proses pelayanan yang lebih trasnparan, terjadi kontrol masyarakat yang lebih kuat, dan pengawasan yang bersifat lekat waktu, Berkurangnya praktek-praktek korupsi, tata hubungan yang lebih ramping, peningkatan efisiensi pemerintah di semua proses belanja 
sektor publik, efisisensi dalam skala ruang dan waktu, struktur dan organisasi informasi yang tersistematisasi dan peningkatan manajemen dari sumber daya baik dari sisi peningkatan bidang kendali maupun sumber daya organisasinya.

Sejalan dengan penelitian sebelumnya yang menyatakan bahwa upaya yang dilakukan oleh Direktorat Jenderal Pajak yang dituntut untuk dapat mengakomodasi keinginan masyarakat untuk mendapatkan pelayanan yang baik, khususnya pelayanan publik yang diberikan oleh pemerintah, telah melakukan berbagai upaya untuk mendapatkan solusi yang tepat yaitu dengan penerapan Good Governace pada setiap pelayanan yang diberikan (Siagian, 2008). Penerapan Good governance dapat terlaksana dengan baik dengan dukungan dari sumber daya manusia dan sistem teknologi informasi yang mendukung terbentuknya sistem administrasi modern. Sumber daya manusia dipersiapkan dengan matang untuk mendukung reformasi administrasi perpajakan dengan diterapkannya sistem administrasi perpajakan modern merupakan salah satu agenda utama dalam blue print kebijakan DJP. Dibentuknya suatu struktur organisasi yang bersifat one-sizefits-all dalam menentukan kebijakan umum untuk menciptakan prinsip Good Governance yang pada dasarnya tidak hanya bergantung pada pendekatan prinsip juga instrument organisasi yang termasuk di dalamnya yang harus secara efektif dapat memanfaatkan mereka agar bisa tercapai prinsip kepatuhan (Pamuk, 2008).

\section{Simpulan, Keterbatasan dan Implikasi Hasil Penelitian}

Berdasarkan perumusan masalah dan tujuan penelitian, maka dapat disimpulkan bahwa moralitas pajak adalah motivasi instrinsik untuk membayar pajak yang timbul dari kewajiban moral atau keyakinan untuk berkontribusi kepada negara dengan membayar pajak. Budaya pajak merupakan keseluruhan interaksi formal dan informal dalam suatu institusi yang menghubungkan sistem perpajakan nasional dengan praktik hubungan antara aparatur pajak dengan wajib pajak, dimana secara historis melekat dengan budaya nasional, termasuk ketergantungan dan ikatan yang terbentuk akibat interaksi yang berkelanjutan, dan Penerapan good governance akan lebih mengoptimalkan peranan informasi teknologi karena memudahkan pelaksanaan proses bisnis dan meningkatkan kemampuan kompetitif.

\section{Daftar Pustaka}

Ayee, Joseph R. A. 2008. Building Tax Compliance through Reciprocity with Government. University of Ghana, Legon.

B. Ilyas, Wirawan dan Richard Burton. 2007. Hukum Pajak. Salemba Empat: Jakarta

Gunadi, Prof. Dr. 2012. Keberhasilan Pajak Tergantung Partisipasi Masyarakatnya, dalam Perspektif Baru. http://www. perpsektif.net/articles/view.asp?id=431

Harinurdin, Erwin. 2009. Perilaku Kepatuhan Wajib Pajak Badan, Bisnis \& Birokrasi, Jurnal Ilmu Administrasi dan Organisasi, Mei-Agustus 2009, hlm 96-104 Volume 16, Nomor 2.

Iskandar, Slamet. 2012. Sektor Jasa Penyumbang Terbesar Kota Bogor. Majalah investasi.

James., I., Sanchez., dan Francisco Gomez. 2008. Economic and Non-economic Factors in Tax Compliance. KYKLOS, 48(1): 8-18.

Nurmantu, Safri.2003. Pengantar Perpajakan, Jakarta, Kelompok Yayasan Obor hal. 1

Pandey, V .2003., Relationship between Personality and Managerial Performance", Central Test Psychology International, www. centraltest.com/accessed_on_Mar02_2013.

Supriyanto. 2011. Pengantar Metodologi Penelitian Bisnis (revisi). Jakarta: Salemba Infotek.

Theresia, Rintha. 2009. Penerapan Good Governance Pada Direktorat Jenderal Pajak, http://lontarui.ac.id

Torgler, Benno 2003. Tax morale and Institutions, Center for Research in Economics, Management and The Arts, September 2003,hal.4.

Widodo, Widi. 2010. Moralitas, Budaya dan Kepatuhan Pajak. CV Alfabeta, Jakarta.

Yamin, Sofyan. 2009. Generasi Baru Mengolah Data Penelitian dengan Partial Least Square Path Modeling : Aplikasi denganSoftware XLSTAT, SmartPLS, dan Visual PLS. Jakarta: Salemba Infotek. 